\title{
ALGORITMA PEMROGRAMAN
}

\author{
KHOIRUL AMRI (0305202123) \\ Program Studi Pendidikan Matematika-4 \\ Fakultas Ilmu Tarbiyah dan Keguruan UIN Sumatera Utara \\ Jl. William Iskandar Pasar V, Medan Estate
}

\begin{abstract}
$\underline{\text { Abstract }}$
For a student, Programming Algorithm is a very important basic subject. Good mastery of programming Algorithm mastery is a good and absolute thing that is very much needed. This is very helpful in the smooth study of students. This article will also discuss the Flowcharting Technique, and also discuss the basic BASIC programming language which is very useful for students, especially in computers. And in this discussion, we will also discuss learning to program and programming languages, Independent Algorithm Notation Against Programming Languages and Computer Machines, procedural programming, and much more that will be discussed in this article, and also this article will discuss the uses of algorithms in everyday life. day .
\end{abstract}

Keywords: Programming Algorithms, Flowchart Techniques, Basic Basic Programming Languages, Independent Algorithm Notation, Procedural Programming

\begin{abstract}
$\underline{\text { Abstrak }}$
Bagi seorang mahasiswa mata pelajaran Algoritma Pemrograman merupakan mata ajaran dasar yang sangat penting. Penguasaan yang baik terhadap penguasaan Algoritma Pemrograman suatu hal yang baik dan mutlak yang sangat diperlukan. Hal ini sangat membantu dalam kelancaraan studi mahasiswa. artikel ini juga akan membahas tentang Teknik Diagram Alur atau Flowcharting,dan juga membahas mengenai bahasa pemrograman BASIC dasar yang sangat berguna bagi para mahasiswa terutamanya dalam komputer. Dan dalam pembahasan ini juga akan membahas tentang belajar memprogram dan bahasa pembrograman, Notasi Algoritma Independen Terhadap Bahasa Pemrograman Dan Mesin Komputer,pembrograman prosedural,dan masih banyak lainnya yang akan dibahas didalam artikel ini,dan juga artikel ini akan membahas kegunaan algoritma dalam kehidupan sehari hari.
\end{abstract}


Kata Kunci : Algoritma Pemrograman, Teknik Diagram Alur, Bahasa Pemrograman Basic Dasar,Notasi Algoritma Independen,Pemrograman Prosedural

\section{PENDAHULUAN}

Dijaman sekarang ini perkembangan teknologi telah berkembang dengan sangat pesat bahkan hampir semua diwilayah belah dunia ini mengenal teknologi,jadi dengan perkembangan teknologi tersebut tidak bisa dipungkuri bahwa kita tidak akan mengikutinya,jika kita tidak mengikutinya maka kita nantinya akan ketinggalan oleh zaman dan tidak akan bisa bersaing dengan yang lainnya sehingga kita nantinya akan dipandang oleh orang lain dengan sebelah mata.namun, bagi mereka yang tidak mau mengikutinya maka mereka harus bersiap siap untuk turun atau mundur dari panggung kompetesi dari perkembangan teknologi ini. Kita dapat mengibaratkan bahwa teeknologi komputer itu sendiri sudah seberti wabah, yang mana teknologi itu sendiri sudah merambat atau menyeluruh keberbagai belahan dunia manusia.bahkan teknologi komputer itu sendiri telah sampai keberbagai kalangan manusia bahkan sampai keplosok plosok desa. Dan dapt kita lihat pula saat ini bahwa teknologi itu sendiri telah dimanpaatkan oleh berbagai kalangan mulai dari pemerintahan pusat hingga sampai juga kepada pemerintahan desa, dan bukan itu saja masih ada seperti contohnya perusahaan prusahaan,pergyryan tinggi,SMA,SMP,bahkan juga sampai SD semuanya telah menggunakan teknologi komputer.teknologi itu sendiri diminati dikarenakan dapat mempercepat dan mempeermudah suatu tugas atau pekerjaan dari suatu pemrogram.dan perlu diketahui bahwa didalam dunia pemrograman komputer sendiriada dikenal dengan algoritma dan juga banyak bahasa pemrograman, seperti misalkan yaitu seperti $\mathrm{C}, \mathrm{C}++$,basic,java dan masih banyak lainnya.dan oleh sebab itu pada kesempatan ini penulis akan menuliskan dan membahas tentang algoritma pemrograman.

Perlu diketahui bahwa algoritma pemrograman adalah suatu langkah langkah yang ditulis atau disusun yang bertujuan untuk menyelesaikan suatu masalah yang ada dalam pemograman pc. Dan yang harus kita ketahui juga adalah bahwa ketika kita melakukan suatu aktifitas kita tidak akan terlepas dari suatu algoritma,oleh karena itu algoritma juga sangat sering kita temukan didalam kehidupan sehari hari kita.

Dan yang perlu kita ketahui juga bahwa algoritma itu sendiri terdiri dari serangkaian langkah langkah logis yang mana digunakan untuk menyelesaikan suatu masalah,yang mana langkah langkah tersebut disusun secara baik dan sistematis. Dan adapun salah satu tujuan dari algoritma yang perlu kita ketahui adalah dapat melakukan tugas dan perhitunganyang sesuai 
dengan kebutuhan saat menulis suatu program.oleh karena itu jadi ddibutuhkanlah suatu pemrograman dengan keterampilan algoritmik.

\section{Metode Penelitian}

Adapun metode yang dilakukan dalam pembuatan artikel ini adalah dengan menggunakan atau diambil dari jurnal jurnal dan buku buku yang telah diterbitkan. Dalam penelitian ini penulis akan membahas tentang algoritma pemrogramanmmulai dari pengertian algoritma dan pemrograman,teori dan dasar konsep algoritma pemrograman, mengetahui bahasa pemrograman dasar basic, mengetahui teknik dasar,diagram alur, Notasi Algoritma Independen Terhadap Bahasa Pemrograman Dan Mesin Komputer, dan masih banyaak lainnya yang akan penulis bahas didalam artikel ini.

Adapun tujuan pembuatan artikel ini adalah untuk memenuhi:

- Penelesaian tugas pada mata kuliah Algoritma Pemrograman

- Memberikan atau menambah wawasan tentang ilmu algoritma pemrograman

- Memberikan wacana yang baik mengenai pembahasan Algoritma Pemrograman dan lainnya.

Adapun beberapa ketentuan yang dilakukan dalam pembuatan artikel ini adalah sebagai berikut ini:

- Minimal dua buku rujukan tahun terbit minimal tahun terbit 2015

- Minimal ada 10 referensi jurnal, dengan ketentuan tahun terbitnya minimal tahun 2015

- Dalam pembuatan tugas artikel ini jumlah kata ayang ada didalam artikel ini minimal adalah 3000 kata. Penelitian yang ada dalam artikel ini nantinya akan membahas atau meenjelaskan tentang depenisi algoritma pemrograman, teori dan dasar konsep algoritma pemrograman, diagram alur,notasi algoritma independen terhadap bahasa pemrograman dan mesin komputer dan lainnya yang akan dibahas atau diulas oleh penulis didalam artikel ini. Dalam penelitian ini juga nantinya akan membahas tentang perbedaan dari algoritma dengan pemrograman, dan kemudian penulis juga akan menjelaskan hubungan diantara algoritma dengan pemrograman.

\section{Hasil dan Pembahasan}

\section{A.Pengertian Algoritma Pemrograman}

Bila kita tinjau dari asal usulnya kata algoritma memiliki sejarah yang cukup aneh. Kebanyakan orang hanya mengetahui kata Algorism yang artinya adalah menghitung angka dari bahasa arab. Kemudian setelah 
melakukan penelitian yang panjang para ahli bahasa akhirnya menemukan arti dari kata tersebut meskipun hasil tersebut kurang memuaskan, yang mana asal dari kata tersebut adalah berasal dari seseorang yang terkenal yang bernama Abu Ja'far Muhammad Ibnu Musa Al-Khuwarizmi beliau adalah seorang buku arab yang terkenal.

Kata AL-Khuwarizme orang barat membaca kata tersebut dengan Algorism. Abu Ja'far Muhammad Ibnu Musa Al-Khuwarizmi menulis buku yang berjudul "berjudul Kitab Al Jabar Wal-Muqabala" dari judul tersebut kita mengetahui bahwa terdapat akar kata dari "Aljabar" (Algebra). Karena sering dikelirukan oleh kata Arithmetic maka kata Algorishm sehingga menjadi kata Algorithm. Hingga pada akhirnya akibat kekeliruan kata tersebut terjadi perubahan kata diahir yaitu ahiran -shm menjadi -thm. Karena perhitungan dalam angka arab sudah biasa maka akhirnya kata Algorishm ahkhirnya hilang dan diganti dengan kata Algorithm dan selalu dipakai dalam perhitungan sehingga menyebabkan hilangnya makna asli dari kata tersebut. Dan dalam bahasa Indonesia akhirnya diserap dari kata Aalgorithm menjadi kata Algoritma.

Bahasa pemrograman merupakan bagian dari notasi yang dipergunakan dalam mendeskripsikan suatu proses komputasi kedalam bentuk pormat sehingga bisa dibaca oleh manusia dan mesin. Pada umumnya proses komputasi dapat didepenisikan menggunakan konsep matimatika dari mesin turing yang didepenisikan secara formal. Dan pada dasarnya bahasa pemrograman diciptakan hanya untuk memfasilitasi komunikasi yang dilakukan loleh antara manusia dan mesin komputer. Dan sebuah bahasa pemrograman dikatakan dengan Turing Complete jika hanya bisa untuk mendeskripsikan semua komputasi yang dilakukan oleh mesin turing.

\section{B.Defenisi Algoritma}

Langkah langkah yang dilakukan dalam Algoritm ialah harus logis dan harus dapat juga ditentukan benar dan salahnya. Jadi dapat disimpulkan bahwa defenisi dari Algoritma adalah urutan langkah langkah logis penyelesaian masalah yang disusun seecara sistematis dan logis. Sehingga dapat kita lihat bahwa logis merupakan kata kunci dari dalam Algoritma.

\section{C.Notasi Algoritma}

Perlu diketahui bahwa notasi algoritma itu sendiri bukanlah notasi dari pemrograman. Melainkan bahwa notasi algoritma ialah yang dapat digunakan sebaggai notassi pemrograman, adapun notasi algoritmanya adalah sebagai berikut ini:

Descriptive Sentence setrand 
Adapun algoritma ini adalah algoritma yang dibuat atau diciptakan dalam bentuk bahassa manusia yaitu seperti bahasa inggris dan juga bahasa indonesia.

> Pseoudo code

Perlu diketahui bahwa Pseudo code berasal dari dua kata yaitu kata "pseudo" dan "kode". Yang mana Pseudo itu sendiri mengacu kepada imitasi, dan kodenya sendiri mengacu kepada kode yang terkait yang ditulis kedalambahsa pemrograman ataupun komputer. Dan satu hal yang perlu diketahui bahwa kode semu itu digunakan untuk meanggambarkab aliran yang logis dari suatu program dan dengan tidak adanya hubungannya kedalam bahasa pemrograman.

$>$ Flowchart

Flowchart atau yang dikenal dengan bagan alir ini adalah suatu diagram yang akan menggambarkan berupa langkah dari awal suaru kegiatan yang mana dengan menggunakan suati simbol tertentu.

\section{D.Algorritma Merupakan Jantung Ilmu Informatika}

Perlu kita ketahui bahwa Algoritma merupakan Jantung dari komputer atau informatika karena banyak cabang ilmu komputer yang diterminologi oleh algoritm. Tetapi perlu kita ketahui juga bahwa Algoritma bukan hanya berkaitan dengan ilmu komputer atau informatika tetapi Algoritma juga berperan dalam kehidupan sehari hari kita. Banyak kegiatan yang dilakukan dalam kehidupan sehari hari kita yang berkaitan atau berhubungan dengan Algoritma. Oleh karena itu suatu Algoritma harus dinyatakan dalam bentuk yang dapat dimengerti oleh pemroses. Jadi langkah pemroses yang diperhatikan harus; mengerti setiap langkah dalam Algoritma, dan mengerjakan operasi yang bersesuaian dengan langkah langkah tersebut.

\section{E.Mekanisme Pelaksanaan Algoritma Oleh Pemroses}

Program adalah implementasi atau perwujudan dari teknis Algoritma yang ditulis kedalam bentuk bahasa tertentu sehingga bisa dijalankan oleh komputer. Maka dari itu bahwa komputer hanya salah satu pemroses. Jadi agar dapat dilaksanakan komputer maka algoritma harus ditulis dalam notasi bahasa pemrograman sehingga dinamakan menjadi pemrogram.

\section{F.Diagram Alur}

Pemakaian komputer dimasa dewasa ini telah berkembang sedemikian pesatnya sejalan dengan kemajuan teknologi komputer itu sendiri. Berbagai bidang seperti industri,perdagangan,pendidikan,pemerintahan dan lainnya memanfaatkan alat canggih ini.

Kebanyak komputer digunakan untuk memproses dan menyimpan data. Semua yang dilakukan oleh komputer selalu berjalan dengan cepat dan 
hasilnya akurat. Untuk melakukan tugas tersebut maka komputer haruslah diprogram terlebih dahulu.

Sebelum suatu pemrogram dibuat, ada baiknya kalau dibuat logika atau urutan urutan intruksi pemrogram tersebut dalam suatu diagram yang disebut dengan diagram alur (FLOWCHART).

\section{Diagram Alur Secara Umum}

Diagram alur secara umum sering terjadi dalam kehidupan sehari hari, semua kegiatan yang dilakukan tanpa adanya syarat tertentu. Diagram alur berlangsung secara lurus dari atas kebawah.

\section{Diagram Alur Untuk Program Komputer}

Jika diagram alur secara umum membahas atau berkaitan dengan kehidupan sehari hari,berbeda pula dengan diagram alur pada komputer yang mana ini membahas khusus masalh tentang penggunaan dan pepmrosesan data pada komputer. Dalam proses pembuatan program komputer sangatlah baik untuk membuat diagram alurnya. Dalam pembuatan program komputer juga harus menggunakan bahasa pemrograman diantara bahasa pemrograman yang kita kenal yaitu pemrograman BASIC.

\section{G.Belajar Memprogram dan Belajar Bahasa Pemrograman}

Sebelumnya perlu kita ketahui bahwa belajar memprogram dengan belajar bahasa pemrograman yang mana belajar memprogram adalah belajar tentang metodologi dalam pemecahan masalah,kemudian menuangkannya kedalam suatu notasi sehingga mudah untuk dipahami. Sedangkan belajar bahasa pemrograman adalah belajar untuk memakai suatu bahasa aturan aturan dalam tata bahasanya, tata cara pengoperasian compiler nya,intruksi intruksinya,dan kemudian memanfaatkan intruksi intruksi tersebut untuk membuat program yang ditulis hanya dalam bahasa itu saja. Sampai saat ini telah ada puluhan bahasa pemrograman yang dibedakan berdasarkan tujuan dan fungsinya.

\section{H.Algoritma}

Dalam algoritma terdapat aksi yang artinya; menghasilkan efek netto yang terdefenisikan dengan baik dan direncanakan, kemudian kejadian yang terjadi pada selaang waktu terbatas.

I.Notasi Algoritma Independen Terhadap Bahasa Pemrograman Dan Mesin Komputer

Perlu diketahui bahwa notasi algoritma dapat diterjemahkan kedalam berbagai bahasa pemrograman. Seperti misalnya kita bisa bayangkan seperti resep kue, dalam resep kue tersebut bagaimanapun bahasa yang digunakan 
dalam resep tersebut nantinya pasti akan menghasilkan kue yang sama asalkan mengikutu aturan atau langkah langkah resep tersebut. Begitu juga dengan notasi Algoritma.

Jadi dari pembahasan diatas dapat kita simpulkan bahwa didalam komputer juga seperti itu,meskipun setiap komputer memiliki perbedaan teknologinya tetapi pada dasarnya komputer pada umumnya dapat melakukan operasi operasi dasar dan setiap intruksi dalam bahasa mesin menyajikan operasi dasar yang sesuai pada setiap komputer,dan juga menghasilkan hasil efek netto yang sama pada setiap komputer.

\section{J.Pemrograman Prosedural}

Didalam algoritma juga berisi urutan urutan dalam penyelesaian masalah yang ada, jadi dari itu dapat dikatakan bahwa algoritma adalah proses yang procediural. Dalam kamus besar bahasa Indonesia defenisi dari prosedural adalah sebagai berikut;

- Tahap tahap suatu kegiatan untuk menyelesaikan suatuaktifitas yang ada

- Metode yang dilakukan langkah demi langkah yang dilakukan secara eksak untuk memecahkan suatu masalah.

Perlu diketahui juga bahwa dalam perogram procedural , program ini debedakan kedalam kebagian data dan bagian intruksi. Bagian intruksi sendiri terdiri atas sequence (runtutan), yaitu intruksi yang dilakukan secara satu persatu secara berurutan oleh pemroses. Dan juga alur dalam intruksi bisa berubah rubah karena disababkan adanya pencabangan kondisional, sehingga data yang disimpan dalam memory ahirnya dimanifulasi oleh intruksi secara procedural(berurutan), sehingga yang demikian ini kemudian dinamakan menjadi pemrograman procedural.

Dan perlu diketahui juga bahwa masih ada paradigman pemrograman yang lain, yaitu adalah pemrograman fungsional, pemrograman konkuren dan pemrograman deklaratif. Dan disini penulis hanya menjelaskan tentang pembahasan paradigman pemrograman procedural saja.

Dan didalam algoritma juga memiliki keuntungannya sendiri dalam pemakaiannya, diantara kentukan dari menggunakan algoritma adalah; algoritma merupakanbentuk yang sangat cocok atau fleksibel yang bisa kita terapkan keberbagai bahasa pemrograman, dan keuntungan yang paling menonjol ialah algoritma berguna untuk menjadi logika pemecahan pemecahan masalah yang dapat kita buat bertingkat. Itulah dia beberapa keuntungan algoritma yang bisa penulis paparkan,jelas masih banyak keuntungan lainnya dari penggunaan algoritma tersebut.

Jadi dari pembahasan diatas kita dapat simpulkan bahwa Algoritma merupakan;

-Algoritma merupakan logika langkah kerja untuk menyelesaikan suatu masalah 
-Penyusunan aspek yang dilakukan dalam proses logika dari suatu masalah tanpa harus melihat karakteristik dari bahasa pemrograman yang akan digunakan dalam prosese tersebut

-Urutan notasi logika yang dilakukan dalam pemecahan masalah yang dilakukan secara analisis dan terancang akan membawa ketujuannya.

Aadapun contoh algoritma dalam kehidupan sehari hari dapat kita lihat misalkan ialah : membuat kue, panduan merakit komputer, menjahit pakaian dan masih banyak lainnya.

Ada beberapa notasi yang digunakan dalam penulisan algoritma, adapun diantaranya adalah;

-Notasi I ; notasi yang pertama adalah untaian kalimat deskriptif

-Notasi II ; notasi yang kedua adalah notasi Flow Chart (diagram alir)

-Notasi III ; notasi yang ketiga adalah Psudo-code

\section{K.Aturan Penulisan Algoritma}

Ada aturan aturan dalam penulisan algoritma karena yang kita ketahui bahwa algoritma itu sendiri berisi tentang langkah langkah dalam penyelesaian masalah. Dan langkah langkah penulisannya dapat dilakukan dengan notasi apapun,asalkan mudah untuk dibaca dan dipahami. Jadi kesimpulannya ialah bahwa dalam penulisan algoritma itu sendiri tiap orang bebas atau bisa membuat aturan aturan penulisan notasinya sendiri. Namun ada baiknya bahwa agar algoritma mudah untuk dibaca dan dipahami kedalam notasi emrograman maka sebaiknya notasi algoritma yang kita buat berkorespnden dengan notasi bahasa pemrograman yang biasa dipakai dalam secara umum.

\section{Aturan Penulisan Algoritma}

Ada aturan aturan dalam penulisan Algoritma yang harus diperhatikan, dan setiap algoritma selalu terbagi atas tiga bagian, diantara ketiga bagian itu adalah:

Judul (Header)

Judul merupakan bagian dari penulisan algoritma, sebagaimana kita ketahui bahwa judul adalah bagian dari teks algoritma yang kita gunakan untuk mendefenisikan nama atau bagian awal dari sebuah penulisan algoritma yang ingin kita lakukan. Nama algoritma itu sendiri sebaiknya singkat tetapi mudah dipahami dan menggambarkan apa yang akan dibahas atau dilakukan oleh algoritma tersebut.

Kamus (Deklarasi)

Kamu merupakan bagian dari teks algoritma yaitu sebagai bagian atau tempat untuk mendefenisikan suatu kata dari teks :

- Nama Type

- Nama Konstanta

- Nama Variable

- Nama fungsi

- Nama prosedur

Semua nama nama diatas baru bisa dipakai atau digunakan dalam algoritma jika nama nama tersebut sudah didefenisakan terlebih dahulu didalam 
kamus. Yang harus diperhatikan seharusnya adalah dalam penulisan nama tersebut dalam kamus sebaiknya dikelompokkan menurut jenis nama tersebut agar lebih mudah dipahami. dan pendefenisian dari nama fungsi sekaligus akan dilakukan dengan range serta sfesifiknya, sedangkan nama variabel belum terdefenisi nilainya meskipun telah didefenisikan, sedangkan nama konstannta pendefenisiannya sekaligus akan didefenisikan dengan harga konstanta tersebut, dan untuk pendefenisian nama prosedur akan sekaligus didefenisikan dengan parameter atau jika ada dan spesifik prosedurnya.

\section{Algoritma}

Dan yang terahir adalah Algoritma, yang pertama yang perlu kita ketahui adalah bahwa algoritma merupakan bagian inti atau paling peenting dari suatu algoritma,karena algoritma berisi tentang intruksi atau pemanggilan aksi yang telah didefenisikan. dan ada beberapa komponen dalam teks algoritma diantara komponen komponen teks tersebut terdapat dalam pemrograman procedural yaitu dapat berupa ;

- Intruksi dasar berupa seperti input atau output, dan assignment

- Runtutan (Sequence)

- Analisi kasus dan

- Perulangan

Dari setiap langkah algoritma dibaca yaitu dari atas ke bawah. Dan juga yang harus diketahui adalah bahwa urutan deskripsi penulisan tersebut akan menentukan urutan pelaksaanaan perintah dalam program algoritma tersebut.

\section{L.Algoritma Merupakan Jantung Ilmu Informatika}

Perlu kita ketahui bahwa algoritma merupakan jantung bagi Ilmu Komputer dan Informatika.banyak sekali cabang imu komputer yang diacu oleh terminologi komputer. Namun kita juga jangan beranggapan bahwa algoritma itu selalu berhubungan dengan ilmu komputer saj, karena nyatanya dalam kehidupan sehari hari kita saja banyak kita temukan banyak terdapat proses yang dinyatakan dalam suatu algorita. Misalkan seperti cara cara membuat kue atau masakan yang dinyatakan dalam ssatu resep itu juga bisa dinyatakan sebagai suatu atau disebut sebagai suatau algoritma. Pada setiap resep dalam pembuatan makanan atau kue selalu ada langkah langkah dalam proses pemasakannya. Jika langkah langkah pembuatannya tidak logis maka akan mendapatkan hasil yang tidak di inginkan. Misalkan ibu ibu yang mencoba suatu resep masakan kue mereka akan membaca setiap langkah langkah dalam pembuatan makanan tersebut kemudian mengerjakan proses tersebut sesuai dengan resep yang dibacanya tadi. Dan perlu kita ketahui bahwa secara umum pihak atau benda yang mengerjakan suatu proses maka disebut pembroses, pemroses tersebut dapat berupa manusia,komputer,robot atau alat alat elektronik lainnya. 
Pemroses nantinya akan menjalankan suatu proses dengan melakukan algoritma yang telah di aljabarkan tadi dalam proses tersebut.

Dari pembahasan diatas bahwa kita telah mengetahui bahwa melaksanakan algoritma berarti melaksanakan setiap langkah langkah yang ada didalam algoritma tersebut. Pembroses harus meengerjakan sesuatu sesua dengan algoritmanya, tukang memasak kue harus menggunakan algoritma yang sesuai,tukang pianis memainkan lagu berdasarkan algoritmanya atau berdasarkan papan not baloknya, oleh sebab itualgoritma harus dinyatakan dalam suatu bentuk yang dapat dimengerti oleh pembrosesnya tersebut.

M.Notasi Algoritma Independe Terhadap BahasaPemrograman dan Mesin Komputer

Perlu kita ketahui bahwa Notasi algoritma dapat kita terjemahkan kedalamberbagai bahasa pemrograman. Misalkan atau analoginya dapat kita lihat seperti resep kue,yang mana kita ketahui bahwa setiap resep tersebut dapat ditulis dalam bahasa apapun dan tetap menghasilkan hasil yang sama,selama aturan pada semua resep tersebut diikuti dengan baik dan benar.

Demikian juga sama seperti halnya pada komputer,mekipun setiap komputer berbeda beda teknologinya tetapi komputer tetap sama saja dapat dijalankan dengan baik,yang membedakan tiap komputer adalah biaya,kecepatan dan ketelitian suatu komputer tersebut. Dan juga pada sisi yang lain setiap program dalam bahasa tingkat tinggi itu selalu terlebih dahulu diterjemahkan kedalam bahasa mesinsebelum pada akhirnya akan dikerjakan oleh CPU. Dan setiap intruksi yang ada dalam bahasa mesin akan menyajikan operasi dasar yang sesuaia,dan juga akan menghasilkan effek netto yang sama pada setiap komputernya.

Pemrograman Prosedural

Sebagai mana telah kita ketahui bahwa algoritma berisi urutan urutanlangkah dalam penyelesaian suatu masalah.itu artinya bahwa algoritma adalah proses yang procediural. Berikut adalah defenisi prosedural menurut kamus basar bahasa Indonesia yang telah saya rangkum: 1.Yang pertama adalah langkah langah atau tahap tahap untuk menyelesaikan suatu aktifitas.

2.Taktik atau metode langkah demi langkah yang secara eksak dalam memecahkan suatu masalah.

Pada pemrograman ini atau prosedural,program ini dibedakan diantara bagian data dan juga bagian intruksi. Pada bagian intruksi sendiri ini terdiri atas runtuhanatau bahasa lainnya yaitu sequence yang mana yaitu intruksi yang dilakukan secara satu persatudan juga secara berurutan oleh pembroses.dan perlu diketahui bahwa alur intruksi dapat berubahkarena karena terjadinya pencabangan kondisional.

Dan selanjutnya yaitu paradigma yang lainnya adalah pembrograman fungsional, pembrograman konkuren dan juga pembrograman deklaratif. 
Dan pada saat ini saya hanya menuliskan sedikit tentang pemrograman prosedural.

Dan selajutnya adalah keuntungan dari penggunaan algoritma adalah ; lagika dari pemecahan suatu masalah dapat dilakukan secara bertahap atau bertingkat.dan perlu diketahui juga bahwa algoritma merupakan bentuk yang sangat pleksibel yang diterapkan atau digunakan kedalam berbagai bahasa pemrograman.

\section{KESIMPULAN}

Algoritma merupakan urutan langkah langkah logis penyelesaian masalah yang disusun seecara sistematis dan logis. Sehingga dapat kita lihat bahwa logis merupakan kata kunci dari dalam Algoritma. A;goritma juga merupakan vagian penting dari sistem komputer yang perlu diketahui yang mana algoritma terdiri dari brainware,perangkat lunak dan juga perangkat keras. Dan tan ketiga tersebut maka sistem yang ada pada komputer tidak akan dapat dijalankan.

Algoritma juga memiliki kegunaan dalam kehidupan sehari hari yang mana telah kita ketahui diatas algoritma juga merupakan kejadian yang dilakukan atau yang terjadi pada selang waktu yang terbatas. Contoh atau misal algoritma yang ada dalam kehidupan sehari hari dapat kita lihat dari komputer dan dapat juga kita lihat dalam resep pembuatan kue. Yang mana hasilnya akan sama meski menggunakan bahasa yang berbeda tetapi dilakukan dengan cara yang baik atau sesuai dengan resebnya.begitu juga dengan algoritma, algoritma merupakan bagian penting dari pada komputer.

Pembrograman adalah merupakan proses dari pada menulis,menguji dan memperbaiki dan juga memelihara kode yang atau yang membangun dari suatu komputer. Dan kode ini akan dituliskan kedalam berbagai bahasa pembrograman. Dan tujuan dari pembrograman tersebut diantaranya adalah untuk memuat suatu pemrograman yang kegunaannya yaitu dapat melakukan suatu perhitungan atau pekerjaan yang diinginkan dari seorang pemroses atau pembrograman untuk melakukan pemrograman tersebut. Dan perlu dketahui bahwa untuk melakukan pemrograman diperlukan keahlian atau kemampuan didalam algoritma,logika,dan bahasa pemrograman, dan pada banyak kasus yaitu yang dipelukan yaitu pengetahuan matematika. Dan adapun contoh dari suatu pembrograman adalah BASIC, C, C++, COBOL, FORTRAN, ada, Pascal, Java , .NET, Bahasa Assembly. Itulah dia beberapa contoh dari suatu pembrograman. Jadi intinya dalam melakukan pembrograman diperlukan ahli yang sudah pandai atau yang mengerti betul tentang pembrograman dan komputer.

Perbedaan diantara Algoritma dengan Pemrograman adalah; pertama tama algoritma adalah langkah langkah untuk menyelesaikan masalah,sedangkan 
program sendiri adalah realisasi dari algoritma yang ada dalam bahasa pemroraman. Dan perlu kita ketahui bahwa adalah bahwa Program sendiri itu ditulis kedalam salah satu bahasa pemrograman, dan juga yang harus kita ketahui adalah bahwa program itu ditulis kedalam satu bahasa pemrograman dan suatu kegiatan membuat program sendiri itu disebut dengan programming.

Agar kita mudah dalam memahami algoritma dan pemrograman,disini penulis memberikan salah satu cara agar kita bisa memahami algoritma dan pemrograman yaitu dengan melakukan ilustrasi atau visuaisasi pada algoritma tersebut. Sebagai contoh sederhananya adalah algoritma sweb, aitu inti dari suatu algoritma tersebut adalah dengan memindahkan nilai dari suatu variabel ke variabel lainnya.

Dan perlu kita ketahui bahwa aAlgoritma sendiri itu memiliki beberapa sifat yang ada padanya diantaranya ialah : pertama tama adalah menerima input, kemudian yang kedua adalah proses entri kedalam beberapa langkah dan selanjutnya adalah setiap langkah tersebut harus didefenisikan dengan baik dan efektif. 
Daftar Pustaka

Jurnal Teknik Mesin (JTM): Vol. 06,Edisi Spesial 2017 https://media.neliti.com/media/publications/177019-IDpembelajaran-dasar-algoritma-dan-pemrogr.pdf

Jurnal Ilmu Komputer dan Informatika. Vol5, No 2 (2021). http://jurnal.uinsu.ac.id/index.php/algoritma

JURNAL INFORMATIKA \& MULTIMEDIA, Vol. 10, No. 2, Tahun 2018. http://repository.ubaya.ac.id/34132/1/\%5B1\%5D\%20Jurnal\%20 Nasional.pdf

Suryadi dan Agus Salim.2016. Memperkenalkan algoritma dan teknologi flowchart pemrograman dan bahasa dasar dasar. Depot : Guna Dharma.

Naufal, Mohammad Farid. 2018. Analisis pembelajaran pemrograman dan teknologi

pendidikan di universitas dan industri. Majalah ilmu komputer dan multimedia.

Volume10, No. 2.

Bagus, Kadek serta Teristha Udayana. 2018. Bawah. Harian Bisnis serta Teknologi

Politeknik. Jil. 5, Nomor. 1.

Cheanna, Andy. 2017. Pelaksanaan algoritma tripod pada robot hexapod menggunakan

Arduino Mega128. JurnalPenelitianInformatikaPostaland. gulungan7,

Tamaymo. (2015). Makalah Algoritma dan

Pemograman,

https://burangasitamaymo.wordpress.com/2015/06/25/makalahalgoritma-dan- pemrograman/ 
Indra, Yatini B., 2010, Flowchart, Algoritma dan Pemrograman Menggunakan

Bahasa C++ Builder. Yogyakarta : Penerbit Graha Ilmu

https://id.wikipedia.org/wiki/Pemrograman

Suhabiebi.( 2016). Modul Bawah Algoritma Serta

Pemprograman. Wordpress. com 